\title{
California Indians and Their Environment: An Introduction
}

\section{Catherine Cocks}

CALIFORNIA INDIANS AND THEIR ENVIRONMENT: An Introduction. By Kent G. Lightfoot and Otis Parrish. Berkeley: University of California Press. 2009.

What is a guidebook? A superficial survey of complex realities? A shield against social engagement for the mere tourist, the traveling dilettante who wants exotic people and things retail and user friendly? ${ }^{1}$ Or, perhaps, as with Kent Lightfoot and Otis Parrish's contribution to the California Natural History Guides series, California Indians and Their Environment, a guidebook is an introduction to the most up-to-date, creditable research on its topic. ${ }^{2}$ I present this distinction so starkly in order to trouble it, for tourist guides are reference works - catalogs of important sights, transportation services, and important phone numbers - and reference works are guides, telling us what to see and how to think about it. This similarity should come as no surprise. Popular and scholarly studies of culture have been uneasy rivals ever since they branched off from the same root during the professionalization of knowledge in the late nineteenth century. But the politics of that rivalry continue to be heated and unhelpful in understanding what it is about culture that attracts both scholars and tourists.

In light of the century-old estrangement between professional and amateur students of culture, it is something of a misrepresentation to call this book, an essay on pre-contact life in California and a scientific listing of the animal, plant, 
and mineral resources then used by indigenous peoples, a guidebook in the usual sense. Lightfoot and Parrish offer the reader only a few hints on how to visit the contemporary indigenous peoples of California or see the remnants of pre-contact life: two pages on cultural centers and celebrations (257-58). They do not discuss the casinos that are the most visible sign of the state's Native residents today. And yet this book shares the aims of many twentieth-century travel guides: to reveal what is hidden, to valorize what has been ignored or denigrated, and to transform the reader through an encounter with it. Ever since the early years of the last century, the concept of culture has contained a progressive politics oriented toward these aims, and it motivated (and continues to motivate, despite powerful critiques) much cultural anthropology, cultural history, cultural studies - and much tourism. The typical nineteenth-century American traveler went abroad, usually to Europe, in service to civilization. The twentieth-century tourist was far more likely to seek culture - particularly the customs, handicrafts, music, and dance of other peoples. Scholarship in the social sciences and humanities experienced a similar shift. ${ }^{3}$

In this essay, I argue that recognizing the affinity between guidebooks for tourists and guidebooks for scholars enriches our understanding of both. In closing, I offer another way to read California Indians and Their Environment - as an invitation to cultural studies scholars and historians to incorporate archaeology into their work while respecting that discipline's distinctiveness and the inappropriateness of extending "America" too far back into the past. As the reader can tell, mine is not a book review in the traditional sense. For that, I urge readers to seek archaeology and natural history journals.

Both guidebooks and scholarly works seek to make what is hidden visible or what is inexplicable understandable. Guidebooks often tell us to abandon our preconceptions and learn the truth by reading their pages. Such rhetoric was particularly common in the early twentieth century, when a growing range of places began to compete with Europe and, as a result, had to make the case first against prevailing assumptions of their dullness or dangerousness. In 1932, the Mexican tourist magazine Real Mexico put that claim right in its title, and continued: "If ReAL MeXico can convince you that Mexico is NOT a lawless land where foreigners are NOT wanted, if ReAL MEXico can prove to you that the land below the Río Grande has beauty, climate and a history unsurpassed by any other country in the world, if REAL MeXico 'sells' you a worthwhile country, then, and only then will it serve its purpose. ..."4 Indeed, over the course of the twentieth century, the Mexican federal government quite successfully deployed culture to consolidate a fractious nation, construct and circulate globally a flattering national image, and improve its international balance of payments. ${ }^{5}$

The authors of California Indians and Their Environment intend to provide anthropologists and botanists with an accurate overview of the natural resources that California's indigenous peoples used - and sometimes still use - to feed, shelter, and transport themselves, celebrate rituals, and make art. This goal may seem quite unlike that of Real Mexico. But to achieve their aim, Lightfoot and 
Parrish have to peel back layers of misunderstanding and present Native Californians in light of what they did do, not what they didn't do: "In taking a fresh look at California Indians, our perspective is that rather than forcing them into models and concepts developed elsewhere, we should pay special attention to those cultural practices and organizational forms that make them different" (7). Doing so, they argue, will make the state's indigenous peoples, past and present, "relevant" to non-indigenous residents - relevancy being to scholarship what commercial success is to tourism.

To make their case, Lightfoot and Parrish argue that California's first residents have long been nearly invisible in the state's (and even more so the nation's) social landscape following the near success of late nineteenth-century campaigns of genocide against them; the best known, Ishi, is famous precisely for having been the last of the Yahi people. But the authors show that, though many died, many also survived: the state now has 108 federally recognized Indian groups and about 150,000 residents who claim Native Californian ancestry (3). Even when visible, though, California's indigenous past has been largely denigrated or neglected by scholars because it does not fit into common assumptions about the rise of human civilization. It is easier to think about, notably, using the concept of culture - the idea that human societies can only be evaluated on their own merits, not in the context of a grand scheme of human development. The numerous diverse societies that inhabited the area during some thirteen thousand years before the arrival of Europeans did not practice agriculture; nor did they build political units much larger than that of the village, although they did participate in regional trade networks. They remained what archaeologists call "hunter-gatherers," but unlike most other people in this category, they were not nomadic. They lived in stable villages and circulated through well-defined territories to harvest a wide range of natural resources $(34-35,79,124-28)$.

In the evolutionary scale developed by early nineteenth-century anthropology, the failure to settle down and build elaborate social hierarchies leading to political aggrandizement looks like a failure to progress. But, as travelers are constantly advised, "[I]f the manners and customs of all countries were alike there would be scant reason for, or pleasure in, traveling." ${ }^{.6}$ Quite the contrary; experiencing this alternative way of life may encourage us to rethink our own assumptions about what makes a decent way of life. The belief that travel—or learning about different ways of life - is broadening has been a central element of tourism at least since the origins of mass pleasure travel in the early nineteenth century. President Franklin D. Roosevelt's purpose in declaring 1940 "Travel America Year" was to "invite our own citizens, and friends from other lands, to join in a great travel movement, so that our peoples may be drawn even more closely together in sympathy and understanding." If tourism has often failed to deliver on this promise, so too has the scholarly concept of culture fallen short of its progenitors' intellectual and political hopes for it. Yet, although culture is not sufficient to the aims it contains, both tourists and scholars persist in seeing 
in it the first step, at least, toward altered ways of thinking and being, ways that might be better.

Just so, Lightfoot and Parrish implicitly criticize the teleological bias in archaeological models of human civilization by arguing that first recognizing and then respecting an alternative model will transform our understanding of humanity. Against the persistent idea that indigenous Californians were backward, the authors insist rather that their modes of interacting with, shaping, and managing the natural world were "sophisticated"- probably the adjective most often used in the introductory essay. With a deep knowledge of their habitats, they regularly deployed controlled burns to encourage the plants and animals most useful to them (94-122). Their reliance on a wide range of resources, rather than the farmer's few staple crops, motivated them to employ practices that sustained the state's enormous biodiversity (69-70). This broad resource base served them well in times of drought, flood, or other natural disasters; when one source of food or clothing was scarce, others were readily available (129-30). Instead of shaking our heads over the failure of Native Californians to develop fine pottery, the authors suggest, we should admire their technically and aesthetically masterful baskets - highly versatile and, unlike ceramic vessels, easily portable (18-20).

In light of such evidence, we must reconsider both our assumptions about human social evolution and our relationship with the environment, a rethinking that invokes the politics of the culture concept. The contrast between the pre-contact past and today's California-regularly devastated by wildfires and dominated by sprawling urban areas, strenuously maintained mono-crop fields of European plants, polluted air and water, and inadequate, shrinking water supplies - could not be more stark. Making this alternative visible is one of the central ethical aims of the book: "[T]raditional Native practices may provide important insights in the development of sustainable economies in California. ... [Indigenous people's] emphasis on local, small-scale enterprises that are ecologically sensitive may be prudent for us to consider in developing sustainable food production economics in California today" (147). The authors do not explicitly argue that smaller political units corresponded to this more environmentally sustainable lifestyle, but the idea is unavoidable - if also unattainable in the foreseeable future.

This idea - that supposedly "primitive" peoples can show us the error of "civilized" ways - is by now hoary-headed. The indigenous peoples of the Americas in particular have served Europeans and Euro-Americans as foils reflecting what is wrong with their own societies since the moment of contact. In the twentieth century, many Americans regarded indigenous and African-descended peoples as reservoirs of unalienated humanity whose wisdom might rescue whites from the psychological, moral, and physical ills of machine-age civilization. ${ }^{8}$ Writing to a friend about her visit to Mexico in 1937, tourist Elise Haas earnestly recited the received wisdom of her time: "What a lesson we hurrying, scurrying Americans can learn from the leisurely Mexican and how many tired, strained faces could be smoothed into serenity by the calm, unhurried manner of living of these people." ${ }^{\prime 9}$ The twentieth-century tourist industry and several regional 
governments made such ideas central to their marketing campaigns for destinations in what seemed then to be extremely unlikely places, such as the barren deserts of New Mexico and Arizona, the steamy, mosquito-ridden Caribbean islands, and violence-plagued Mexico. ${ }^{10}$

It's easy to be cynical about this kind of romanticism. It is obviously a form of what Renato Rosaldo famously named "imperialist nostalgia," and its focus on individual emotion and small-scale interactions tends to veil structural inequities with a rhetoric of mutual exchange and personal connection. Twentiethcentury tourism, like many popular forms of cultural encounter, typically offers consumable difference without questioning the circumstances of its production. And yet, romanticism was one of the forebears of the somewhat more politically robust cultural pluralism, and the desire for difference that inhabits both does not necessarily serve the status quo. ${ }^{11}$ To deny that we might learn from other ways of doing - that is, to deny the progressive impulse within the romantic questioning of civilization - ultimately concedes the inevitability of our condition. At the heart of many critiques of tourism is just this denial, the belief that cultural contact in a context of structural inequality can only perpetuate the inequality. The fact that it often does so does not mean that it always must, or that the hope that it won't is illegitimate, though it may well be naïve.

Nor is scholarship free of either the romantic impulse or structural inequality. There are two ways in which Lightfoot and Parrish can be accused of a romantic approach to their subject. First, they present a largely admiring portrait of ecologically sensitive, politically and socially flexible pre-contact peoples who had solved the omnivore's dilemma, in stark contrast to today's Californians. ${ }^{12}$ To defend themselves against the accusation of idealization, the authors also note the archaeological evidence for violence, inequality, and resource depletion before the arrival of Europeans (85-89). It wasn't paradise, they say, but pre-contact societies suffered comparatively few of the problems that plague the state today.

A more serious flaw appears in their presentation of contemporary California Natives. The book's focus is on the past, so people alive today appear only occasionally. When they do, they are mostly cultural experts - carvers (192-93), language teachers (214-15), basket makers (305-07), and potters (343-44), but also scholars, archaeologists, and ecologists (121; and author Otis Parrish is a scholar and a Kashaya Pomo elder, 493). As a result, like most tourist guidebooks, this book gives the impression that contemporary Native peoples mainly care about arts and rituals - "cultural" things - and not so much about political and economic matters such as water rights, land reclamation, or gaming compacts. Yet Lightfoot and Parrish have successfully demonstrated that the ways of life that pre-contact peoples developed were deeply rooted in a particular political economy. Surely in addition to managing fire to produce the resources they wanted, these societies must also have cultivated the skills necessary to maintain a multiplicity of small, independent polities in a crowded landscape - the ability to negotiate wisely, bargain shrewdly, and if necessary, wage war successfully. 
Perhaps their descendants manifest these values, too, as politicians and business people.

Counteracting this rather traditional treatment of contemporary indigenous peoples is the book's focus on the complex manipulation of natural resources, which tends toward a persuasive kind of environmental determinism. The authors cope with the overwhelming number of polities in pre-contact California (34, map 2) by abandoning any effort to tell specific histories. Instead, they group indigenous societies according to their location in one of six geomorphic provinces (61, map 4). This approach tends to place the state's indigenous peoples in a timeless ethnographic past, something the authors reject (48-49) but nevertheless reproduce by painting in such broad strokes. ${ }^{13}$ But the emphasis on the successful manipulation of nature to promote both human welfare and biodiversity and the suggestion that this strategy offers a model for the future offsets the potentially stultifying effects of both environmental determinism and the absence of history. Rather than imperialist nostalgia, the authors recommend that we rethink the nature of culture: A degree of environmental determinism might be a good thing. People's cultures ought to be less determined to overcome the limits - and the vast power - of the natural world, and more determined to find ways to live successfully with both.

There is a way, finally, in which California Indians and the Environment is also a guidebook in the more usual sense: it enables the reader to identify the plants, animals, insects, and rocks and minerals that Native peoples used to make food, shelter, clothing, and tools. Making up two-thirds of the text are short, illustrated descriptions of these resources, organized regionally so that the hiker in the Sierra Nevada and the kayaker along the southern coast will be able to identify the flora and fauna around them. Of course, like sightseeing and souvenir-buying, botanizing reflects the will to collect and classify that characterized every European and American imperial enterprise. ${ }^{14}$ Yet it also expresses a progressive desire to understand the natural environment and even, as this book urges, to live in it less destructively.

This doubleness is neatly expressed in the book's use of Latin names to supplement the English names of the items listed, absorbing them into the epistemological system of Euro-American civilization. Yet what else could be done? The system dominant today constitutes a lingua franca of a kind that probably did not exist in pre-contact California, with its hundreds of languages; it is, ironically, one of the more useful products of the civilized fantasy of total control over the natural world. Latin names offer many people access to knowledge in a way that invites them to cherish plants and animals that once nourished quite other societies and might even help transform the existing one. Discovering this hidden landscape of Native resources, even cloaked in Latin, reveals a once and future possibility for a human existence that enhances, rather than degrades, biological diversity. 
There's another way to read California Indians and Their Environment - as an invitation to broaden the scope of American Studies and U.S. history in yet another new direction. While attention to the uses of nature is by now a familiar element in cultural studies, archaeological research is much less so, not least because archaeology is an old and highly developed field with roots as deep in the natural sciences as in the social. Historians and cultural studies scholars might consider drawing upon insights into a much deeper past in the same light as they do transcending national boundaries. Advocates of the latter see it as a way to overcome the old-fashioned exceptionalism that was long one of the organizing principles of American Studies and U.S. history and to acknowledge that cultures are rarely co-extensive with national boundaries. The same can be said of attending to the pasts that existed in North America long before "America," much less the United States of America, was even imagined. Just as California's current political economy is only the most recent in a long chronicle of human ways of exploiting the region's geological and biological diversity, the United States is a comparatively new and young instance of human social organization. Attending to the ancient and recent pasts that preceded the arrival of Europeans in the western hemisphere can humble any version of "America." Then too, a book like California Indians and Their Environment allows the historian or cultural studies scholar to do more than simply gesture vaguely at a rich indigenous past. With it, we can talk concretely about sophisticated, diverse responses to the necessary interaction of humanity with the environment.

Of course, critics argue that transnationalization threatens to engulf everybody in the western hemisphere into an "American" paradigm, mirroring longstanding U.S. economic and political hegemony. Incorporating pre-American pasts into something called "American Studies" or "U.S. history" poses the same risk. Every pre-contact society had its own trajectory-and, if it survived colonization, still does to the extent possible or desirable to its members. Indigenous peoples in the Americas may or may not imagine themselves as "American" and may or may not wish to contest that forced belonging. Lightfoot and Parrish, notably, do not address the contemporary political aspirations of Native Californians, no doubt because they are far afield from the book's focus on life before European colonization. In more present-minded works, we should be aware that the project of reimagining a more knowledgeable, broad-minded America may not be one to which Native people want to lend their past or present.

Bringing a little archaeology into the study of contemporary cultures also presents another opportunity. Archaeologists in most cases do not have texts or informants; they have only things. In fact, often what they have is, literally, trash. For students of the ancient past, any "culture" they find is materially determined, which is not to say that archaeology or archaeologists are determinists, but rather that because of the nature of their evidence, they must have a great respect for the material. The care with which archaeologists theorize about the relationship between objects and the intangible realm of belief and practice offers a valuable, if often unsettling, perspective for those of us blessed with the rich textual 
archives of the last few centuries. Taking a hard look at interpretive practices in this light might encourage more respect for both material constraints and human creativity in their embrace.

\section{Notes}

1. Daniel Boorstin, The Image: A Guide to Pseudo-Events in America (New York: Harper \& Row, 1964), and Paul Fussell, Abroad: British Literary Traveling between the Wars (New York: Oxford University Press, 1980), are among the better known writers to have articulated this view of tourism and tourists, but it remains common and animates much academic writing on tourism.

2. Kent Lightfoot and Otis Parrish, California Indians and Their Environment: An Introduction, California Natural History Guide Series no. 96 (Berkeley: University of California Press, 2009). Henceforth I will give page references in the text.

3. Four of the many histories of the culture concept: Adam Kuper, Culture: The Anthropologists' Account (Cambridge, MA: Harvard University Press, 1999); Susan Hegeman, Patterns for America: Modernism and the Concept of Culture (Princeton, NJ: Princeton University Press, 1999); Diana Selig, Americans All: The Cultural Gifts Movement (Cambridge: Harvard University Press, 2008); James W. Cook and Lawrence B. Glickman, "Twelve Propositions for a History of U.S. Cultural History," The Cultural Turn in U.S. History: Past, Present \& Future, edited by James W. Cook, Lawrence B. Glickman, and Michael O’Malley (Chicago: University of Chicago Press, 2008): 3-57; on travel, a survey of the existing secondary sources supports this point, but to be brief, see Jonathan Rée, "Cosmopolitanism and the Experience of Nationality," Cosmopolitics: Thinking and Feeling Beyond the Nation, edited by Pheng Cheah and Bruce Robbins (Minneapolis: University of Minnesota Press, 1998): 81.

4. Real Mexico 1:1 (April 1932): 4. A publication of the Consolidated Railroad and Pullman Company Tourist Service, with the cooperation of the Departamento del Distrito Federal de México. This publication was produced in English for U.S. residents.

5. Dina Berger, Development of Mexico's Tourism Industry: Pyramids by Day, Martinis by Night (New York: Palgrave Macmillan, 2006); Catherine Cocks, "The Welcoming Voice Of The Southland: American Tourism Across The U.S.-Mexico Border, 1880-1940," Bridging National Borders in North America, edited by Benjamin H. Johnson and Andrew Graybill (Durham, NC: Duke University Press, 2010).

6. T. Philip Terry, Terry's Guide to Cuba, Including the Isle of Pines (Boston and New York: Houghton Mifflin Company, 1926), 200.

7. File: Tourist and Winter Residence Development-General, box 1313, 9-11-42 Virgin Islands/Tourist Development, Office of the Territories Classified Files, 1907-1951, Department of the Interior, Record Group 126, National Archives and Records Administration. An expression of the Good Neighbor policy, this declaration was also part of the Roosevelt administration's campaign against German and Japanese influence in Latin America by building closer ties among the countries of the western hemisphere and combating white American prejudices against Latin Americans.

8. Robert Berkhofer, The White Man's Indian: Images of the American Indian from Columbus to the Present (New York: Knopf, 1978); David Arnold, The Problem of Nature: Environment, Culture and European Expansion (Oxford: Blackwell, 1996): 141-149; Marianna Torgovnick, Gone Primitive: Savage Intellects, Modern Lives (Chicago: University of Chicago Press, 1990); Margaret Jacobs, Engendered Encounters: Feminism and Pueblo Cultures, 1879-1934 (Lincoln: University of Nebraska Press, 1999); Philip Deloria, Playing Indian (New Haven, CT: Yale University Press, 1998).

9. Elise S. Haas, Letters from Mexico (San Francisco: Privately printed, 1937): 6.

10. Leah Dilworth, Imagining Indians in the Southwest: Persistent Visions of a Primitive Past (Washington, DC: Smithsonian Institution Press, 1996); Catherine Cocks, "The Pleasures of Degeneration: Climate, Race, and the Origins of the Global Tourist South in the Americas," Discourse 29:2-3 (Spring-Fall 2007): 215-235.

11. Renato Rosaldo, "Imperialist Nostalgia," Representations 26 (Spring 1989): 107-122; Rebecca Steinitz, "The Illusion of Exchange: Gift, Trade, and Theft in the Nineteenth-Century British Voyage Narrative," LIT 7:2-3 (1996): 153-165; Mary Louise Pratt, Imperial Eyes: Travel Writing and Transculturation (New York: Routledge, 1992); Cocks, "Welcoming Voice"; Julia Harrison, Being a Tourist: Finding Meaning in Pleasure Travel (Vancouver: UBC Press, 2003), ultimately condemns the well-meaning Canadian travelers that she studies for their complicity in the structural inequities shaping their journeys. But no traveler today can escape these structures, so scholars of tourism and tourists must consider not simply the politics of travel but also the politics of staying home.

12. Michael Pollan, The Omnivore's Dilemma: A Natural History of Four Meals (New York: Penguin Press, 2006).

13. Johannes Fabian, Time and the Other: How Anthropology Makes Its Object (New York: Columbia University Press, 1983), on the ethnographic present; the same situation often prevails 
with general descriptions of ancient peoples, who have cultures but not histories. Archaeologists have the good excuse, however, that historical events often simply aren't visible in the evidence and at the time scales in which they work.

14. Pratt, Imperial Eyes; Felix Driver and Luciana Martins, eds., Tropical Visions in an Age of Empire (Chicago: University of Chicago Press, 2005). 
